\title{
An efficient green synthesis of polyfunctional pyrazole-triazole hybrids and bis- triazoles via chromium incorporated fluorapatite encapsulated iron oxide nanocatalyst
}

\author{
Iman Rezaei ${ }^{\mathrm{a}}$ and Manouchehr Mamaghani ${ }^{\mathrm{a}^{*}}$
}

${ }^{a}$ Department of Chemistry, Faculty of Sciences, University of Guilan, P.O. Box 41335-1914, Rasht, Iran

\begin{tabular}{l} 
C H R O N I C L E \\
\hline Article history: \\
Received December 18, 2020 \\
Received in revised form \\
April 23, 2021 \\
Accepted April 23, 2021 \\
Available online \\
April 26, 2021 \\
\hline Keywords: \\
Nanocatalyst \\
Triazole \\
Pyrazol \\
Green chemistry \\
Fluorapatite \\
\end{tabular}

\begin{abstract}
A B S T R A C T
In this report, novel chromium incorporated fluorapatite encapsulated iron oxide $(\gamma$ $\mathrm{Fe}_{2} \mathrm{O}_{3} @$ FAp@Cr) nanocatalyst was synthesized and characterized by FT-IR, TEM, SEM, XRD and EDX techniques. The catalyst was used in the synthesis of various derivatives of pyrazoletriazole hybrids via the reaction of thiosemicarbazide or semicarbaside and pyrazolecarbaldehydes at room temperature with excellent yields and short reaction times. The protocol was also used in the synthesis of bis-triazoles in high yield and reasonable reaction time. The nanocatalyst was comfortably separated from the reaction mixture by an external magnet and was reused in six consecutive cycles without any remarkable changes in its catalytic performance.
\end{abstract}

\section{Introduction}

Nitrogen containing heterocyclic rings are momentous groups in organic chemistry. Derivatives of triazole rings are an essential aromatic five-membered heterocycles presenting important biological activities $^{1-7}$. Some of these compounds have shown anti-bacterial ${ }^{8,9}$, anti-fungal ${ }^{10}$, antiinflammatory $^{11,12}$, anti-tumor ${ }^{13,14}$, antimalarial ${ }^{15,16}$ and anti-cancer ${ }^{17,18}$ properties. Numerous derivatives of triazole rings are widespread in natural product and pharmacological compounds. Some representative examples are presented in Fig. $\mathbf{1}^{19-26}$. Therefore, various methods and catalysts have been introduced for the synthesis of triazole derivatives such as, application of a microwave-assisted click chemistry using copper(I) ${ }^{19}$, samarium doped fluorapatites ${ }^{27},\left[\mathrm{C}_{16} \mathrm{MPy}\right] \mathrm{AlCl}_{3} \mathrm{Br}$ as ionic liquid ${ }^{28}$ and potassium hydroxide ${ }^{29}$. Nevertheless, the most general method for the synthesis of five-membered heterocycles is $[3+2]$ cycloaddition reaction which has been recently discussed in detail ${ }^{30}$. Some of the reported procedures suffer from harsh reaction conditions, complex synthetic pathways and non-

* Corresponding author.

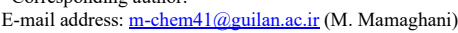

(c) 2021 Growing Science Ltd. All rights reserved. doi: $10.5267 / \mathrm{j} . c c 1.2021 .4 .006$ 
recyclability of the catalyst. Consequently, more facile synthetic methods are still required. To achieve this objective, we developed an efficient protocol by using the magnetic chromium incorporated fluoroapatite $\left(\gamma-\mathrm{Fe}_{2} \mathrm{O}_{3} @ \mathrm{FAp} @ \mathrm{Cr}\right)$ as a novel catalyst for the green synthesis of versatile polyfunctional pyrazole-triazole hybrids in short reaction time (10-60 min) and excellent yield (88-95\%). Interestingly, the method was also extended to the synthesis of bis-triazoles successfully.<smiles>[R]n1n(C)c2c(=O)c3ccccc3c(=O)c=2n1Cl</smiles>

Antibacterial<smiles>[R]n1cc(CNS(=O)(=O)c2ccc(N)cc2)nn1</smiles><smiles>[R][X]c1ccc(/C=C/C(=O)/C=C/c2ccc(CCc3cn(-c4ccnc5cc(Cl)ccc45)nn3)c(OC)c2)cc1</smiles><smiles>[R]n1cc(C(=O)NC(=O)c2cn([R])nn2)nn1</smiles>

Fig. 1. Some representative triazole derivatives with biological properties ${ }^{19-26}$.

\section{Results and Discussion}

Following our continued studies in the benign synthesis of biologically important heterocycles ${ }^{31-39}$, we have developed a convenient method for the efficient synthesis of mono- and bis-triazole in the presence of newly synthesized magnetic nanocatalyst $\left(\gamma-\mathrm{Fe}_{2} \mathrm{O}_{3} @ \mathrm{FAp} @ \mathrm{Cr}\right)$. Initially, the requisite $\gamma-$ $\mathrm{Fe}_{2} \mathrm{O}_{3} @$ FAp was prepared according to the literature report ${ }^{37,38}$ and reacted with $\mathrm{CrCl}_{3} .6 \mathrm{H}_{2} \mathrm{O}$ in water at room temperature to furnish the desired catalyst (Scheme 1). The structure of the catalyst was established by FT-IR, XRD, SEM, EDX and TEM.

\section{FT-IR analysis}

In the FT-IR spectra of $\gamma-\mathrm{Fe}_{2} \mathrm{O}_{3} @ \mathrm{FAp} @$ Cr NPs the bending vibrations of P-O-P which are overlapping with the stretching vibration of $\mathrm{Fe}-\mathrm{O}$ are visible at 589 and $604 \mathrm{~cm}^{-1}$. The stretching vibrations of P-O bands appeared at $1039 \mathrm{~cm}^{-1}$. The broad and strong band at $3415 \mathrm{~cm}^{-1}$ belongs to the stretching vibrations of $\mathrm{O}-\mathrm{H}$ groups and absorbed water (Fig. 2).

\section{XRD analysis}

Fig. 3 shows the XRD analysis of the $\gamma-\mathrm{Fe}_{2} \mathrm{O}_{3} @ \mathrm{FAp} @ \mathrm{Cr}$ catalyst in contrast to $\gamma-\mathrm{Fe}_{2} \mathrm{O}_{3}$ and $\mathrm{FAp}$. This pattern shows characteristic peaks at around $2 \theta=35.7^{\circ}, 48.7^{\circ}, 52.4^{\circ}, 53.4^{\circ}, 56.2^{\circ}, 63.3^{\circ}$ which are readily distinguished from the XRD pattern. They agree with the cubic structure of maghemite (JCPDS file No. 39-1346). Diffraction peaks at around $2 \theta=26.1^{\circ}, 28.2^{\circ}, 29.2^{\circ}, 32.0^{\circ}, 33.2^{\circ}, 34.3^{\circ}$, $40.1^{\circ}, 46.9^{\circ}, 49.7^{\circ}, 51.7^{\circ}, 78.7^{\circ}$ are related to the FAp (JCPDS File No. 003-9137). The average crystallite size was calculated to be 25 nm for $\gamma-\mathrm{Fe}_{2} \mathrm{O}_{3} @ \mathrm{FAp} @ \mathrm{Cr}$ using the Scherrer equation. 


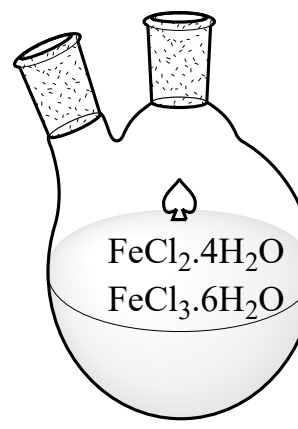

(i) $\mathrm{NH}_{4} \mathrm{OH}$

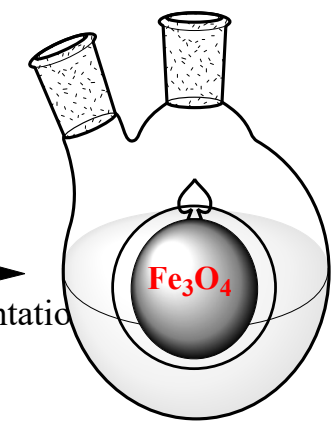

(i) water, TBAF,

10 min vigorous stirring

(ii) solution of $\left(\mathrm{NH}_{4}\right)_{2} \mathrm{HPO}_{4}$

(ii) magnetic decantatio

$+\mathrm{Ca}\left(\mathrm{NO}_{3}\right) \cdot 4 \mathrm{H}_{2} \mathrm{O}$

(iii) heat $80^{\circ} \mathrm{C}, 1 \mathrm{~h}$

(iv) cooling to r.t.

(v) aging overnight

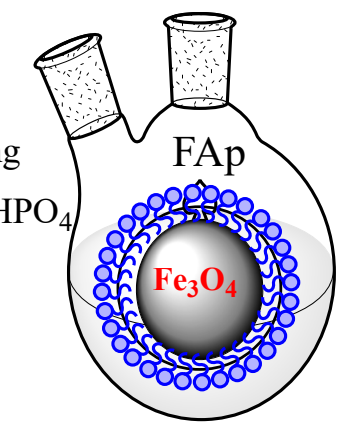

$\mathrm{Fe}_{3} \mathrm{O}_{4} @ \mathrm{FAp}$

(i) magnetic decanttion

(ii) wash with water

(iii) air dring under vacum ar r.t

(iv) calcination $300^{\circ} \mathrm{C}, 3 \mathrm{~h}$

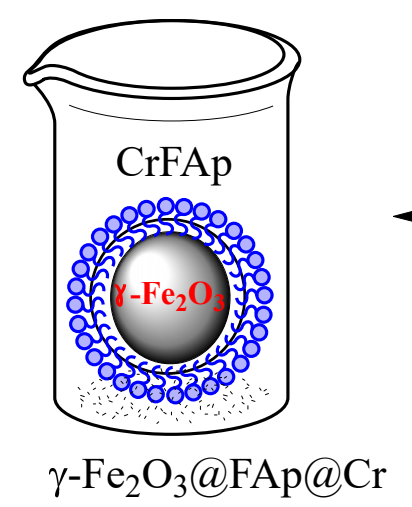

(i) water

(ii) $\mathrm{CrCl}_{3} \cdot 6 \mathrm{H}_{2} \mathrm{O}$, stirr at $80{ }^{\circ} \mathrm{C}, 1 \mathrm{~h}$

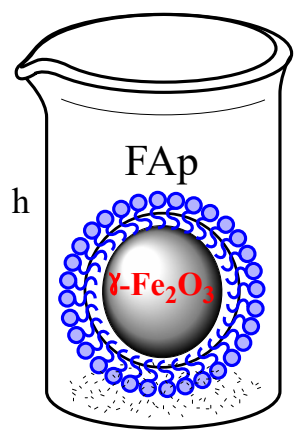

$\gamma-\mathrm{Fe}_{2} \mathrm{O}_{3} @ \mathrm{FAp}$

Scheme 1. Synthesis of $\gamma-\mathrm{Fe}_{2} \mathrm{O}_{3} @ \mathrm{FAp} @$ Cr NPs.

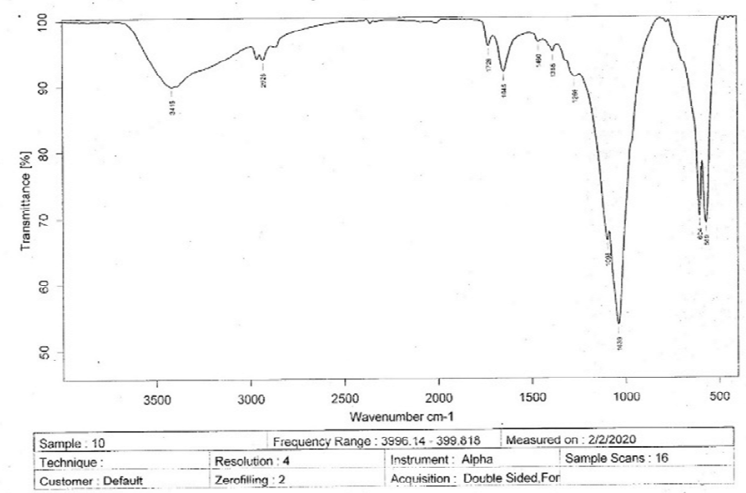

Fig. 2. The FT-IR spectra of $\gamma-\mathrm{Fe}_{2} \mathrm{O}_{3} @ \mathrm{FAp} @ \mathrm{Cr}$ 


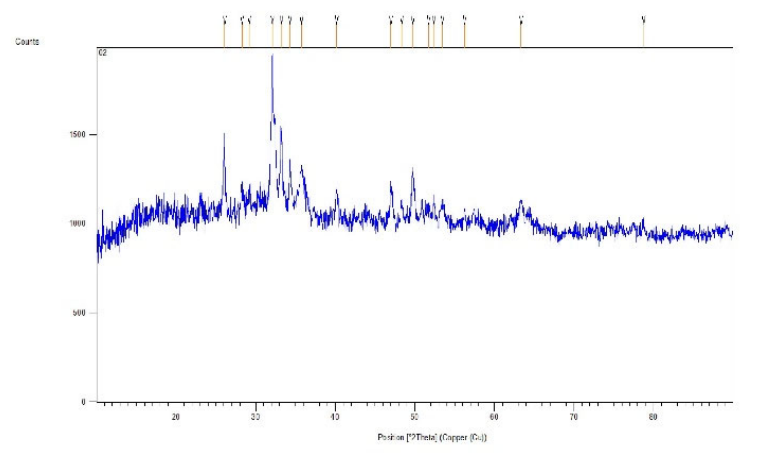

Fig. 3. The XRD image of $\gamma-\mathrm{Fe}_{2} \mathrm{O}_{3} @ \mathrm{FAp} @ \mathrm{Cr}$

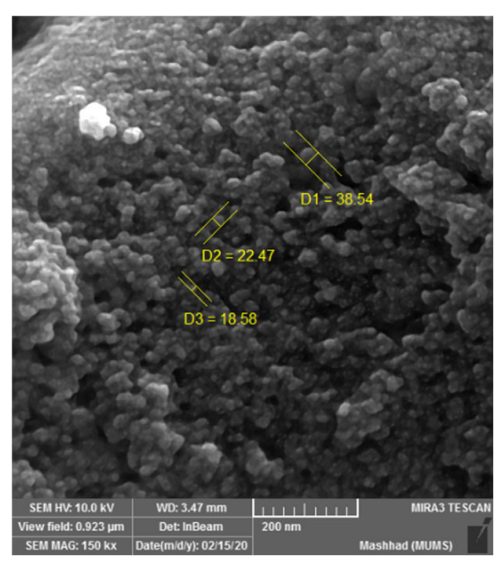

Fig. 4. The SEM image of $\gamma-\mathrm{Fe}_{2} \mathrm{O}_{3} @ \mathrm{FAp} @ \mathrm{Cr}$

\section{Scanning electron microscopy analysis (SEM)}

The morphology and particle size of the $\gamma-\mathrm{Fe}_{2} \mathrm{O}_{3} @ \mathrm{FAp} @ \mathrm{Cr}$ catalyst were investigated using SEM technique (Fig. 4). According to the SEM images $\gamma-\mathrm{Fe}_{2} \mathrm{O}_{3} @ \mathrm{FAp} @ \mathrm{Cr}$ MNPs are formed with almost spherical morphology. The average size of $\gamma-\mathrm{Fe}_{2} \mathrm{O}_{3} @ \mathrm{FAp} @ \mathrm{Cr}$ nanoparticles is about 15-40 nm according to the measurement software.

\section{EDX analysis}

The results of energy dispersive X-ray spectroscopy (EDX) analysis of the synthesized $\gamma$ $\mathrm{Fe}_{2} \mathrm{O}_{3} @ \mathrm{FAp} @ \mathrm{Cr}$ MNPs proved existence of Fe $(24.0 \mathrm{w} / \mathrm{w} \%), \mathrm{O}(48.3 \mathrm{w} / \mathrm{w} \%), \mathrm{P}(7.9 \mathrm{w} / \mathrm{w} \%) \mathrm{Ca}(15.0$ $\mathrm{w} / \mathrm{w} \%), \mathrm{F}(0.7 \mathrm{w} / \mathrm{w} \%)$ and $\mathrm{Cr}(4.1 \mathrm{w} / \mathrm{w} \%)$ atoms in the structure that confirms the presence of $\gamma-\mathrm{Fe}_{2} \mathrm{O}_{3}$ core in the structure of MNPs (Fig. 5).

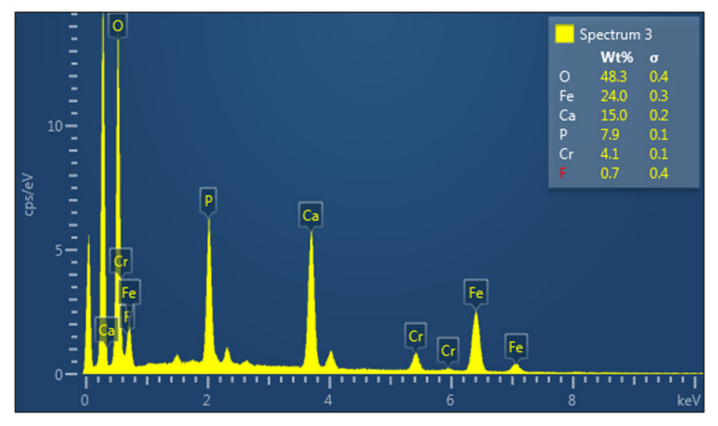

Fig. 5. The EDX image of $\gamma-\mathrm{Fe}_{2} \mathrm{O}_{3} @ \mathrm{FAp} @ \mathrm{Cr}$

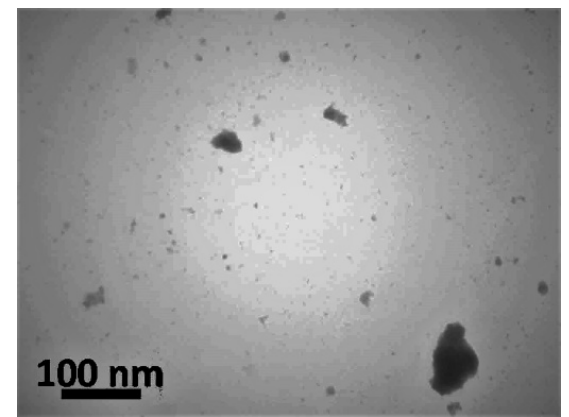

Fig. 6. The TEM image of $\gamma-\mathrm{Fe}_{2} \mathrm{O}_{3} @ \mathrm{FAp} @ \mathrm{Cr}$

\section{TEM analysis}

The morphology and size of the $\gamma-\mathrm{Fe}_{2} \mathrm{O}_{3} @ F A p @ C r$ MNPs were checked by the TEM spectrum as shown in Fig. 6. According to the TEM images analysis, the size of these nanoparticles was estimated $15-25 \mathrm{~nm}$.

In order to study the catalytic capability of the synthesized $\gamma-\mathrm{Fe}_{2} \mathrm{O}_{3} @ \mathrm{FAp} @ \mathrm{Cr}$ nanoparticles in organic reactions, we decided to investigate its activity in a green synthesis of several pyrazole-triazole hybrids (Scheme 1). Therefore, for optimization of the reaction conditions as a model reaction, thiosmicarbazide or semicarbazide (1) and 1,3-diphenyl-1H-pyrazole-4-carbaldehyde (2) in the presence of $\gamma-\mathrm{Fe}_{2} \mathrm{O}_{3} @ \mathrm{FAp} @ \mathrm{Cr}$ nanoparticles in a variety of solvents and various temperatures were reacted (Table 1). 

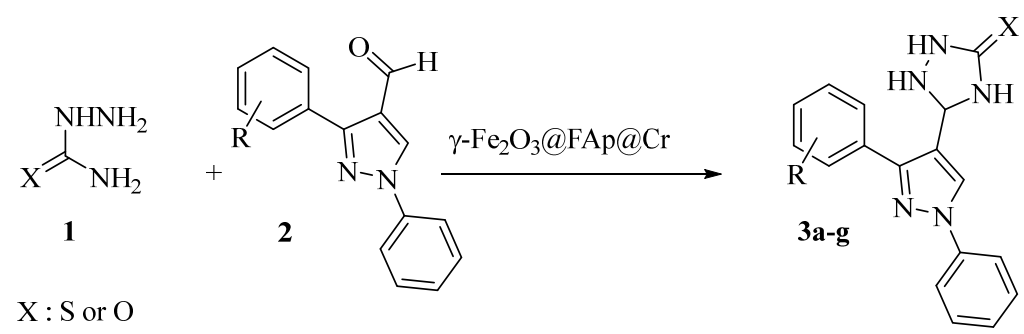

Scheme 1. Synthesis of 5-(3-(aryl)-1-phenyl-1H-pyrazol-4-yl)-1,2,4-triazolidine-3-ones (thiones) derivatives via $\gamma-\mathrm{Fe}_{2} \mathrm{O}_{3} @ \mathrm{FAp} @ \mathrm{Cr}$.

It is evident from the results that using chloroform at room temperature leads to the desired product 5-(1,3-diphenyl-1H-pyrazol-4-yl)-1,2,4-triazolidin-3-thione (3a) in $10 \mathrm{~min}$ and 95\% yield (Table 1, Entry 4). To demonstrate the efficiency of the nanocatalyst the reaction was performed in the absence of the catalyst and in the presence of various acidic and basic catalysts (Table 2). This study revealed that the reaction in the presence of $\gamma-\mathrm{Fe}_{2} \mathrm{O}_{3} @ \mathrm{FAp} @ \mathrm{Cr}$ nanocatalyst produces better result. The amount of the catalyst was also verified which proved that the use of $0.06 \mathrm{gr}(4.7 \mathrm{~mol} \%)$ of the catalyst per mmol substrate provides the best yield of triazolidin-3-thione (3a).

Table 1. Synthesis of 3a in the presence of $\gamma-\mathrm{Fe}_{2} \mathrm{O}_{3} @ \mathrm{FAp} @ \mathrm{Cr}$ in various solvents and temperatures

\begin{tabular}{ccccc}
\hline Entry & Solvent & Temperature $\left({ }^{\circ} \mathrm{C}\right)$ & Time $(\mathrm{min})$ & Yield $(\%)^{\mathrm{a}, \mathrm{b}}$ \\
\hline 1 & Toluene & 25 & 120 & trace \\
2 & $\mathrm{THF}$ & 25 & 120 & 65 \\
3 & $\mathrm{DMF}$ & 25 & 120 & 70 \\
4 & $\mathrm{CHCl}_{3}$ & 25 & 10 & 95 \\
5 & $\mathrm{CHCl}_{3}$ & 40 & 10 & 94 \\
6 & $\mathrm{CHCl}_{3}$ & 60 & 10 & 95 \\
7 & $\mathrm{CH}_{3} \mathrm{CN}$ & 25 & 150 & 80 \\
8 & $\mathrm{H}_{2} \mathrm{O}$ & 25 & 15 & 90 \\
\hline
\end{tabular}

${ }^{a}$ Isolated yield. ${ }^{b}$ Reaction conditions: thiosemicarbazide $1(\mathrm{X}=\mathrm{S})(1 \mathrm{mmol}), 1,3$-diphenyl-1 $H$-pyrazole-4-carbaldehyde 2a $(1 \mathrm{mmol})$, solvent $(3 \mathrm{~mL})$, catalyst $(0.06 \mathrm{gr}, 4.7 \mathrm{~mol} \%)$.

Table 2. Effect of catalyst types on the reaction time and yield of $\mathbf{3 a}$

\begin{tabular}{clcc}
\hline Entry & Catalyst & Time $(\mathrm{h})$ & ${\text { Yeild }(\%)^{\mathrm{a}, \mathrm{b}}}$ \\
\hline 1 & - & 24 & 55 \\
2 & $\mathrm{KSF}$ & 10 & 63 \\
3 & $P$-TSA & 8 & 79 \\
4 & $\mathrm{DABCO}$ & 4 & 82 \\
5 & nano-Fe $_{3} \mathrm{O}_{4}$ & 3 & 87 \\
6 & $\mathrm{CrCl}_{3} \cdot 6 \mathrm{H}_{2} \mathrm{O}$ & 12 & 70 \\
7 & $\gamma-\mathrm{Fe}_{2} \mathrm{O}_{3} @ \mathrm{FAp}$ & 1 & 89 \\
8 & $\gamma-\mathrm{Fe}_{2} \mathrm{O}_{3} @ \mathrm{FAp} @ \mathrm{Cr}$ & $10(\mathrm{~min})$ & 95 \\
\hline
\end{tabular}

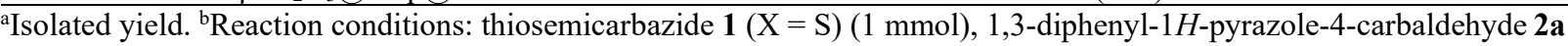
(1 mmol), $\mathrm{CHCl}_{3}$, room temperature, catalyst $4.7 \mathrm{~mol} \%$.

Table 3. Investigation of the amount of catalyst used in the synthesis of $\mathbf{3 a}$

\begin{tabular}{cccc}
\hline Entry & amount of catalyst $(\mathrm{g})$ & Time $(\mathrm{min})$ & Yield (\%) \\
\hline 1 & 0.03 & 20 & 85 \\
2 & 0.06 & 10 & 95 \\
3 & 0.1 & 10 & 95 \\
\hline
\end{tabular}

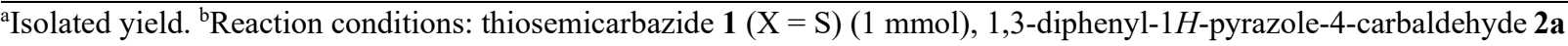
$(1 \mathrm{mmol}), \mathrm{CHCl}_{3}$, room temperature.

This protocol was applied to the synthesis of a variety of pyrazole-triazole hybrids by using substituted pyrazole carbaldehydes (2) under the optimized reaction conditions and the results are presented in Table 4. This study reveals that both thiosemicarbazide (Enties 1-6) and semicarbazide (Entry 7) provide the desired products (Scheme 1) in high to excellent yields (88-95\%) and lower reaction times (10-15 $\mathrm{min})$. 
Table 4. Synthesis of pyrazole-triazole hybrids (3a-g) using $\gamma$ - $\mathrm{Fe}_{2} \mathrm{O}_{3} @ \mathrm{FAp} @ \mathrm{Cr}$ under optimized conditions.

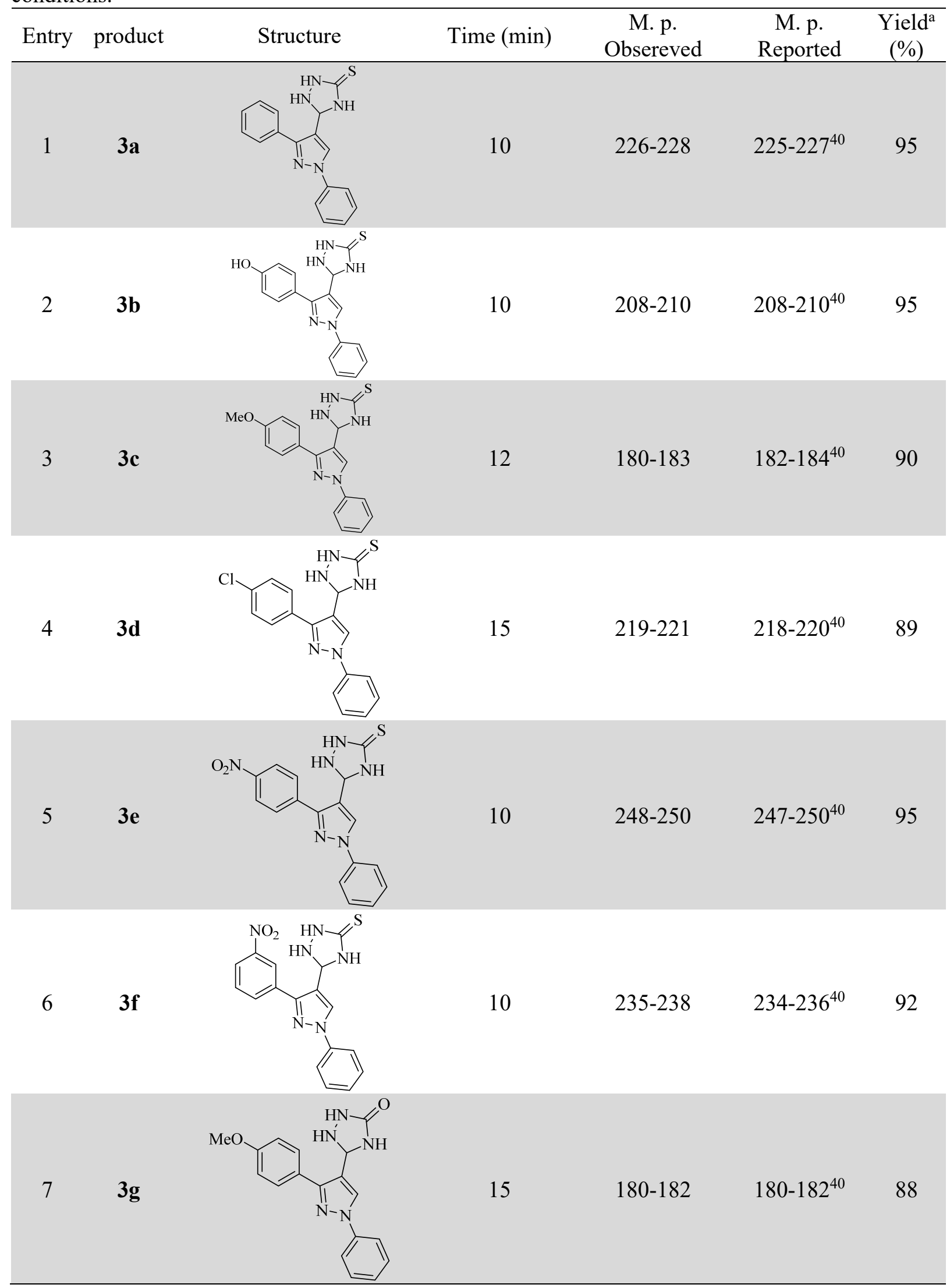

${ }^{\text {a Isolated yield. }}$ 
The synthesis of model compound (3a) in ethanol or methanol at room temperature provided 5alkoxy-3-(3-(3-aryl)-1-phenyl-1H-pyrazol-4-yl)-4H-1,2,4-triazole derivatives (4a-e) (Scheme 2) in excellent yields (Table 5).
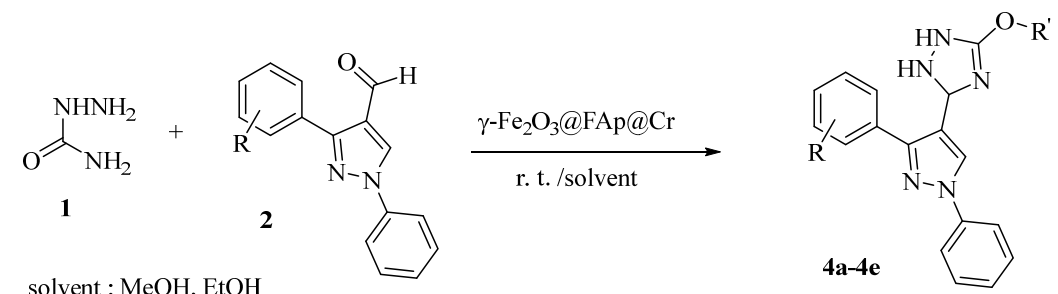

$\mathrm{R}^{\prime}: \mathrm{Me}, \mathrm{Et}$

Scheme 2. Synthesis of 5-alkoxy-3-(3-(3-aryl)-1-phenyl-1H-pyrazol-4-yl)-4H-1,2,4-triazole derivatives via $\gamma-\mathrm{Fe}_{2} \mathrm{O}_{3} @ \mathrm{FAp} @ \mathrm{Cr}$.

Table 5. Synthesis of 5-alkoxy-3-(3-(3-aryl)-1-phenyl-1H-pyrazol-4-yl)-4H-1,2,4-triazole derivatives (4a-e) using $\gamma-\mathrm{Fe}_{2} \mathrm{O}_{3} @ \mathrm{FAp} @ \mathrm{Cr}$.

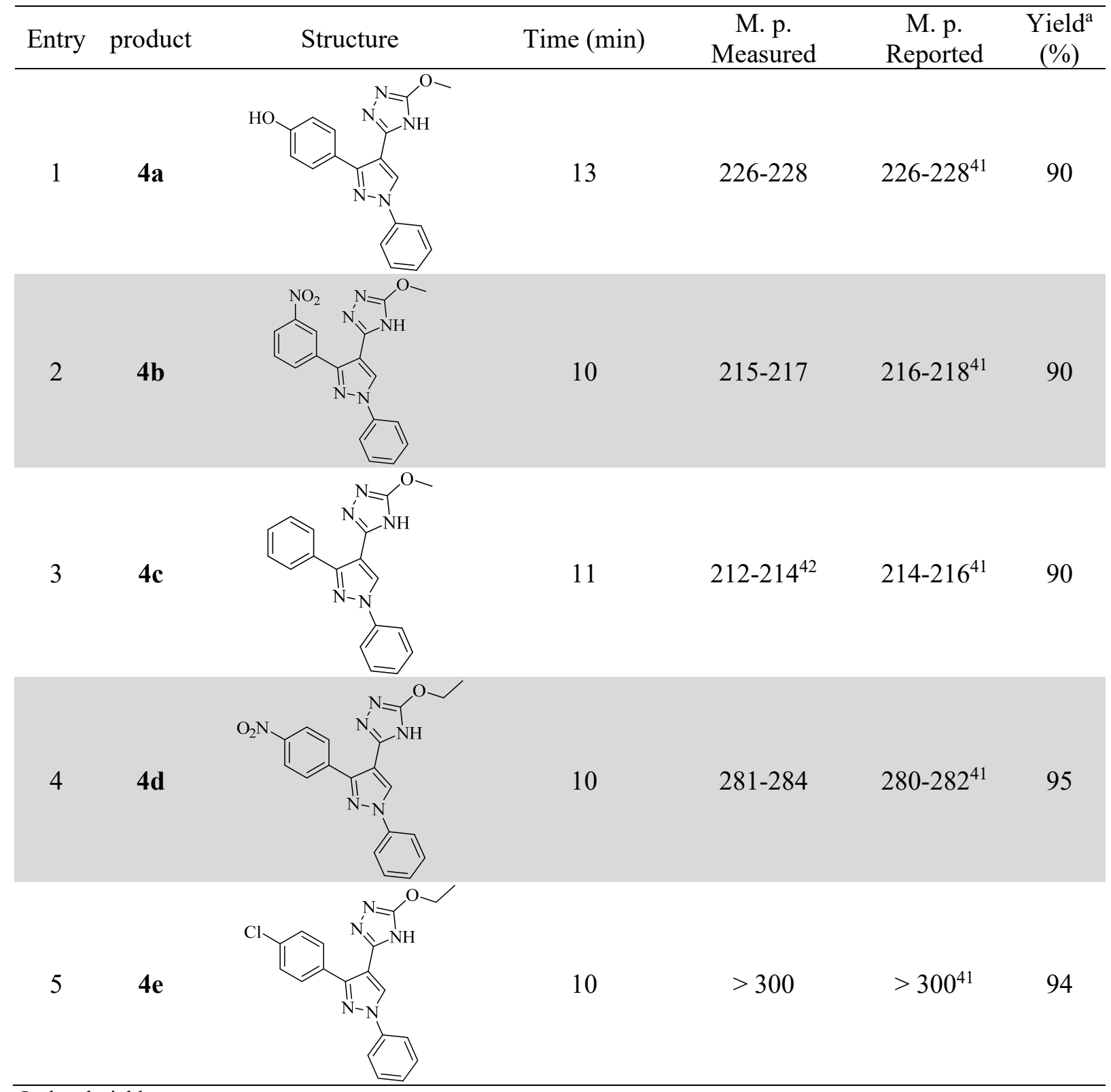

${ }^{\text {a Isolated yield. }}$ 
Interesting results obtained in the synthesis of pyrazole-triazole hybrids (Tables 4 \& 5) encouraged us to extend the scoop of this protocol to the synthesis of bis-triazole derivatives (7a-c) (Scheme 3). Initially, the reaction of 1,4-dibromobutane with thiosemicarbazide resulted in the synthesis of butane-1,4-diyl-bis(hydrazinecarbimidothioate) which then reacted with various aromatic aldehydes to furnish the novel derivatives of bis-triazoles in excellent yields and reasonable reaction times (Table 6). Structure of these new bis-triazole derivatives were established by spectroscopic (FTIR, ${ }^{1} \mathrm{H}$ NMR, ${ }^{13} \mathrm{C}$ NMR, Mass) analyses.

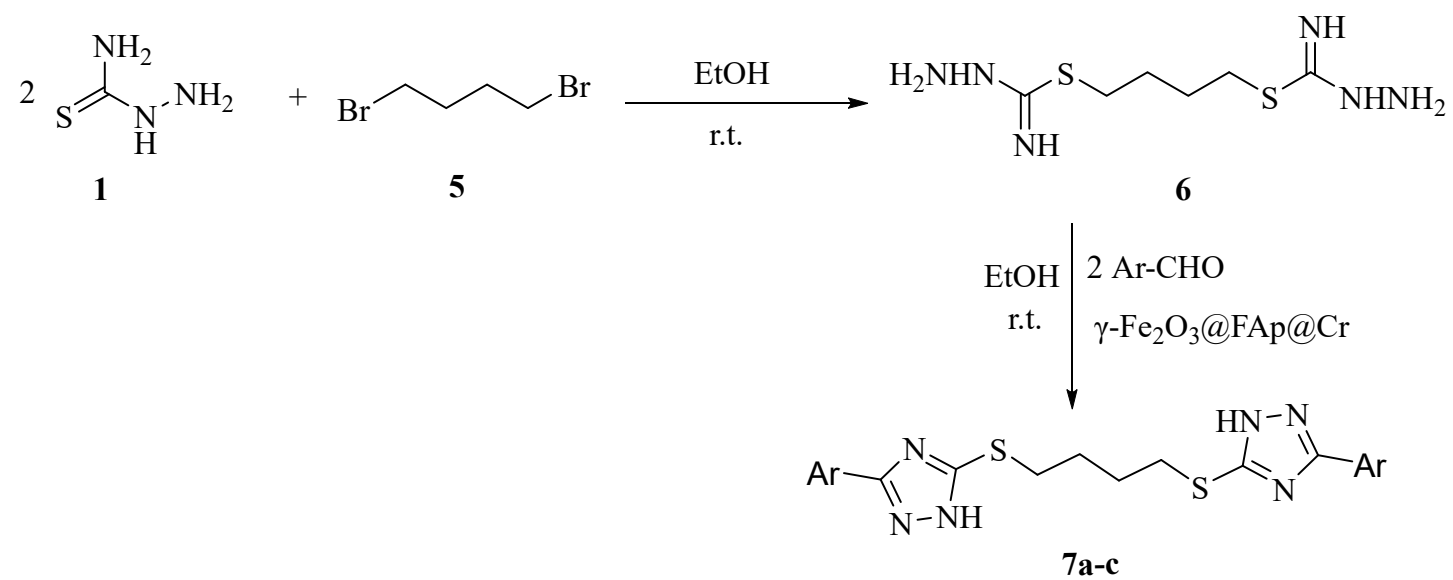

Scheme 3. Synthesis of novel derivatives of bis-triazoles using $\gamma-\mathrm{Fe}_{2} \mathrm{O}_{3} @ \mathrm{FAp} @ \mathrm{Cr}$.

Table 6. Synthesis of novel derivatives of bis-triazoles using $\gamma-\mathrm{Fe}_{2} \mathrm{O}_{3} @ \mathrm{FAp} @ \mathrm{Cr}$ at room temperature.

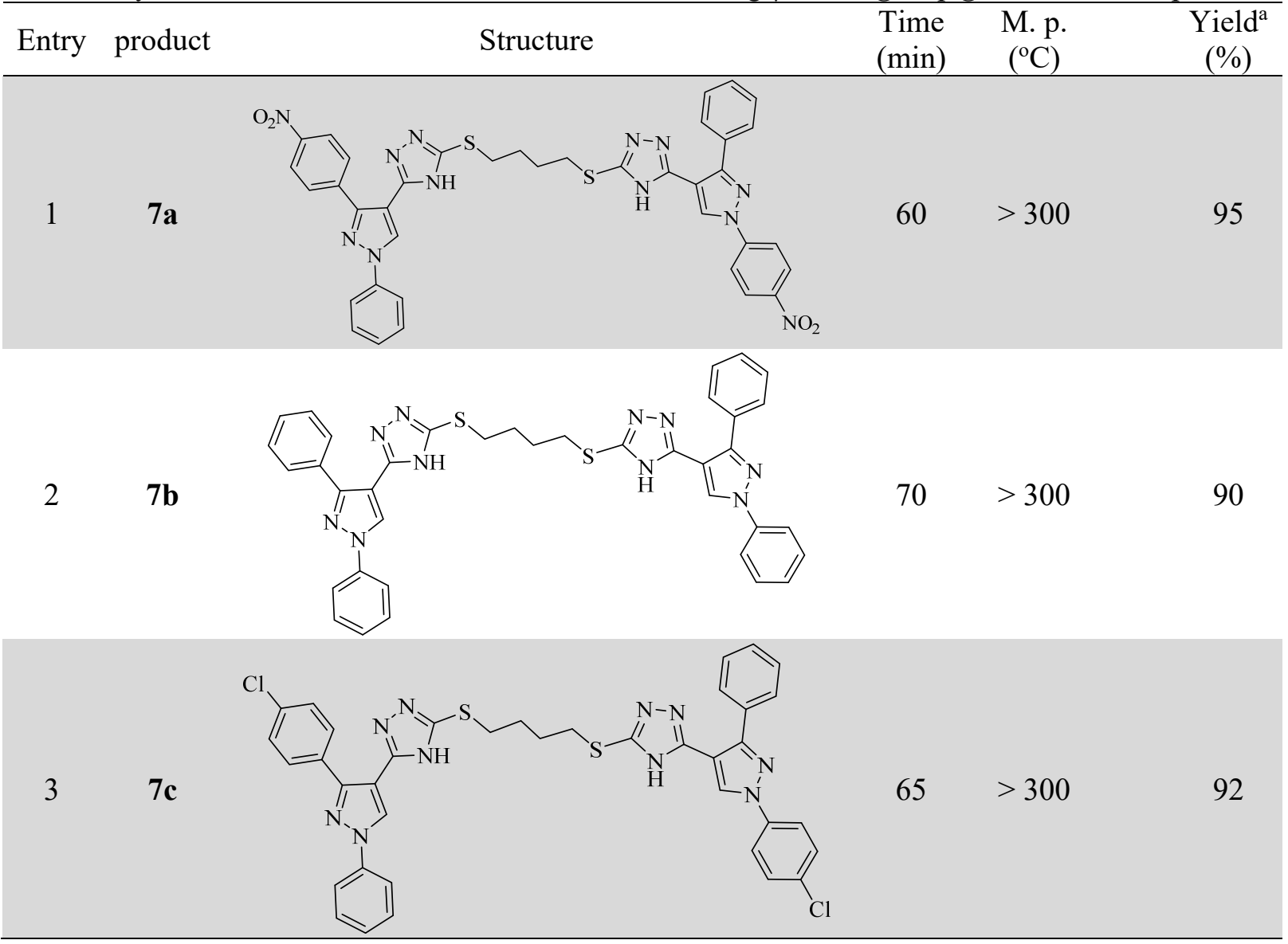

asolated yield. 
A suggested mechanism for the synthesis of triazole derivatives in the presence of chromium incorporated fluorapatite encapsulated iron oxide nanocatalyst $\left(\gamma-\mathrm{Fe}_{2} \mathrm{O}_{3} @ \mathrm{FAp} @ \mathrm{Cr}\right)$ is presented in Scheme 4. Initially, $\gamma-\mathrm{Fe}_{2} \mathrm{O}_{3} @ \mathrm{FAp} @ \mathrm{Cr}$ NPs activate pyrazolecarbaldehyde via coordination to the carbonyl group of the aldehyde. In continuation, thiosemicarbazide or semicarbazide is added to the activated carbonyl group of aldehyde producing arylidene intermediates $\mathbf{A}$ or $\mathbf{B}$ which by interamolecular cyclization furnish the target products 3a-g, $\mathbf{4 a - e}$ and $\mathbf{7 a - c}$.

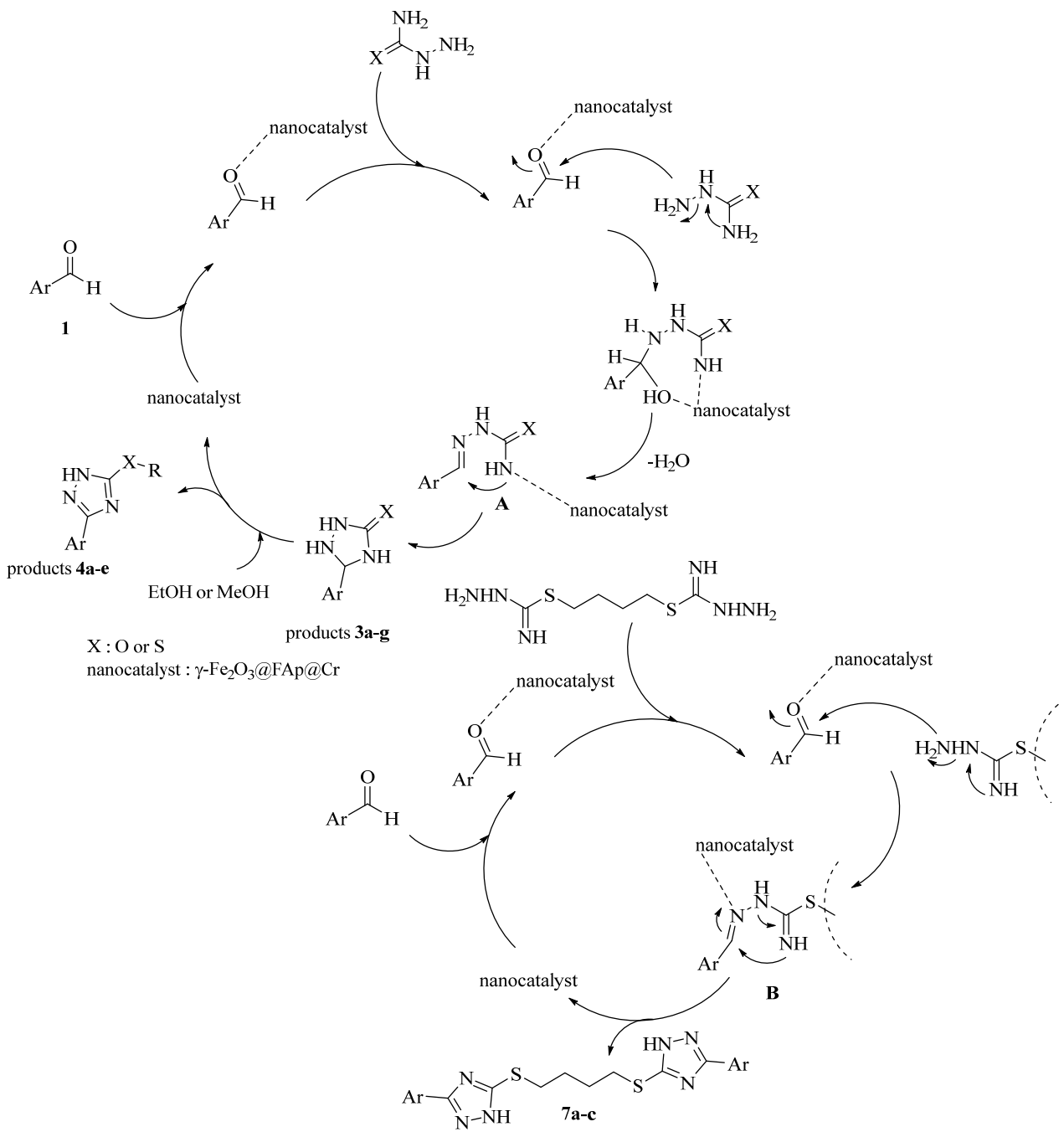

Scheme 5. A proposed mechanism for the synthesis of triazole drivatives using $\gamma-\mathrm{Fe}_{2} \mathrm{O}_{3} @ \mathrm{FAp} @ \mathrm{Cr}$ nanocatalyst.

The recyclability of the catalyst was investigated in the synthesis of model compound 3a. At the end of each reaction the nanocatalyst was separated by an external magnet, washed with hot ethanol, dried at $80^{\circ} \mathrm{C}$ and reused in the subsequent run. This study showed that after six consecutive cycles the catalytic activity was preserved without any striking loss in its catalytic activities (Fig.7).

\section{Conclusions}

We have introduced $\gamma-\mathrm{Fe}_{2} \mathrm{O}_{3} @ \mathrm{FAp} @ \mathrm{Cr}$, as an efficient, novel, inexpensive, eco-friendly and recyclable nanocatalyst, for the synthesis of pyrazole-triazol hybrids and bis-triazoles. The prominent advantages of this method can be described as adherence to the basis of green chemistry, easy work-up procedure without any need for chromatographic separation, short reaction times, excellent yields, facile removal and reuse of the catalyst. 


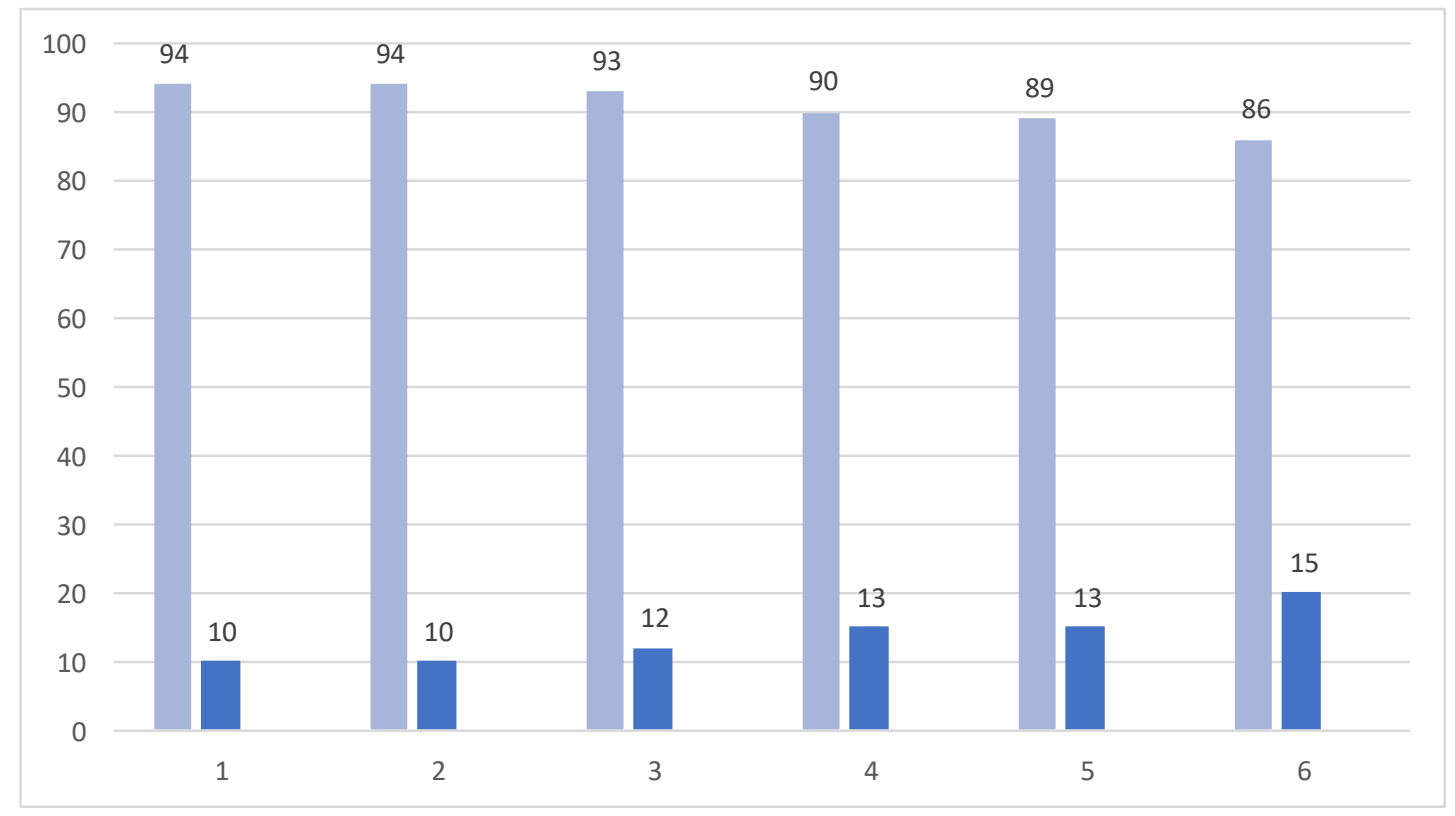

Fig. 7. Recyclability of $\gamma-\mathrm{Fe}_{2} \mathrm{O}_{3} @ \mathrm{FAp} @ \mathrm{Cr}$ in the synthesis of 3a as the model compound.

\section{Acknowledgements}

Partial financial support of University of Guilan for this research work is sincerely acknowledged.

\section{Experimental}

\subsection{Materials and Methods}

Chemicals for this research were purchased from Merck and Fluka. Melting points were determined on a Büchi B-545 apparatus in open capillary tubes. FT-IR spectra were recorded on a $\alpha$-Bruker spectrometer. ${ }^{1} \mathrm{H}$ NMR spectra were recorded on a $300 \mathrm{MHz}$ Bruker DRX-300 in DMSO-d6 as solvent and tetramethylsilane (TMS) as internal standard. ${ }^{13} \mathrm{C}$ NMR spectra were obtained on a $75 \mathrm{MHz}$ Bruker DRX-75 in DMSO-d 6 as solvent. Mass spectra were obtained from AB SCIEX 3200 QTRAP. XRD was done on a KEFA Analytical XPERT-PRO. Scanning Electron Microscope (SEM) were investigated on a model: VP 1450, company: LEO-Germany. Elemental analysis (EDX) was obtained on Oxford Instruments EDS Microanalysis X-MAX-80; model: TeScan-Mira III. Transmission electron microscopy (TEM) measurements were recorded on a Zeiss-EM10C-100 KV instrument. Thin layer chromatography (TLC) was done with ethyl acetate: n-hexane 1:1 on TLC Silica gel $60 \mathrm{~F}_{254}$ 4.2. Synthesis of $\gamma-\mathrm{Fe}_{2} \mathrm{O}_{3} @ \mathrm{FAp} @ \mathrm{Cr} M N P s$

$\gamma-\mathrm{Fe}_{2} \mathrm{O}_{3} @$ FAp MNPs was prepared according to the reports ${ }^{37,38} .125 \mathrm{mg}$ of $\gamma$ - $\mathrm{Fe}_{2} \mathrm{O}_{3} @$ @ FAp was stirred with $2 \mathrm{mmol} \mathrm{CrCl}_{3} .6 \mathrm{H}_{2} \mathrm{O}$ in $25 \mathrm{ml}$ water at room temperature for a period of $1 \mathrm{~h}$. The obtained slurry was magnetic decanted, washed with DW frequently, and dried at $100{ }^{\circ} \mathrm{C}$ to give $\gamma$ $\mathrm{Fe}_{2} \mathrm{O}_{3} @ \mathrm{FAp} @ \mathrm{Cr}$ NPs as a brown solid (655 mg).

4.3. General procedure for the synthesis of 5-(3-(aryl)-1-phenyl-1H-pyrazol-4-yl)-1,2,4-triazolidine3-ones (thiones) and 5-alkoxy-3-(3-(3-aryl)-1-phenyl-1H-pyrazol-4-yl)-4H-1,2,4-triazole derivatives

A mixture of semicarbazide or thiosemicarbazide $(1 \mathrm{mmol})$, aromatic aldehyde $(1 \mathrm{mmol})$ and 0.06 g $\gamma-\mathrm{Fe}_{2} \mathrm{O}_{3} @ \mathrm{FAp} @ \mathrm{Cr}$ were stirred in chloroform $(5 \mathrm{~mL})$ at room temperature for the required reaction time and the progress of the reaction was monitored by thin layer chromatography (ethyl acetate: nhexane 1: 2). After completion of the reaction, $\gamma-\mathrm{Fe}_{2} \mathrm{O}_{3} @ \mathrm{FAp} @ \mathrm{Cr}$ was separated by an external magnet 
(1.4 Tesla) and washed with hot DW and ethanol three times, dried and reused in the next run under similar reaction conditions. The reaction mixture after separation of the catalyst evaporated under vacuum and the residue was recrystallized from ethanol to produce the desired pyrazole-triazole products (Table 4). The reaction in methanol or ethanol as a solvent gave 5-alkoxy-3-(3-(3-aryl)-1phenyl-1H-pyrazol-4-yl)-4H-1,2,4-triazoles presented in Table 5.

4.4. preparation of butane-1,4-diyl-bis(hydrazinecarbimidothioate)

A mixture of 1,4-dibromobutane $(1 \mathrm{mmol})$ and thiosemicarbazide $(2 \mathrm{mmol})$ were stirred at room temperature in ethanol $(5 \mathrm{~mL})$ and the progress of the reaction was checked by TLC (ethyl acetate: nhexane 8: 2). After completion of the reaction, butane-1,4-diyl-bis(hydrazinecarbimidothioate) was obtained as a milky solid with $96 \%$ yield.

\subsection{General procedure for the synthesis of 1,4-bis((3-Aryl-1H-1,2,4-triazol-5-yl)thio)butane}

A mixture of arylaldehyde ( $2 \mathrm{mmol}$ ) and butane-1,4-diyl-bis(hydrazinecarbimidothioate) (1 mmol) and $0.06 \mathrm{~g} \gamma-\mathrm{Fe}_{2} \mathrm{O}_{3} @ \mathrm{FAp} @ \mathrm{Cr}$ were stirred at room temperature for the required reaction time (Table 6) and the progress of the reaction was monitored by thin layer chromatography (ethyl acetate: n-hexane 1: 1). After completion of the reaction, $\gamma-\mathrm{Fe}_{2} \mathrm{O}_{3} @ \mathrm{FAp} @ \mathrm{Cr}$ nanoparticles were separated by an external magnet $(1.4$ Tesla) and washed with hot ethanol three times, dried and reused in the next run under similar reaction conditions. After removal of the catalyst the reaction mixture was evaporated under vacuum by a rotary evaporator. The resulting solid residue was purified by recrystallization from ethanol to produce 1,4-bis((3-aryl-1H-1,2,4-triazol-5-yl)thio)butane in 90-95\% yield.

\subsection{Physical and spectral data of selected compounds}

1,4-bis((3-(3-(4-nitrophenyl)-1-phenyl-1H-pyrazol-4-yl)-1H-1,2,4-triazol-5-yl)thio)butane (7a). Yield 95\%, light brown solid; M. p. $300>{ }^{\circ}$ C. FT-IR (KBr), v, $\mathrm{cm}^{-1}: 3309$ (N-H), 3094, 2976, 2892 $(\mathrm{C}-\mathrm{H}), 1663,1612,1510(\mathrm{C}=\mathrm{C}$ and $\mathrm{C}=\mathrm{N}), 1563,1379\left(\mathrm{NO}_{2}\right), 1253(\mathrm{C}-\mathrm{S}-\mathrm{C}), 827,786,696 .{ }^{1} \mathrm{H}$ NMR (300 MHz, DMSO-d6), $\delta$, ppm: 1.83 (br. s, 2H, $\underline{\mathrm{CH}}_{2}-\mathrm{CH}_{2}-\mathrm{S}$ ), 3.38 (br. s, $2 \mathrm{H}, \mathrm{CH}_{2}-\mathrm{S}$ ), 7.50 (t, J= 7.2 $\mathrm{Hz}, 1 \mathrm{H}), 7.61$ (t, $J=7.5 \mathrm{~Hz}, 2 \mathrm{H}), 7.94$ (d, $J=7.5 \mathrm{~Hz}, 2 \mathrm{H}), 7.99$ (d, $J=8.7 \mathrm{~Hz}, 2 \mathrm{H}), 8.33$ (s, 1H, CH$\mathrm{N}), 8.37(\mathrm{~d}, J=8.7 \mathrm{~Hz}, 2 \mathrm{H}), 9.23(\mathrm{~s}, 1 \mathrm{H}, \mathrm{NH}) .{ }^{13} \mathrm{C}$ NMR spectrum $\left(75 \mathrm{MHz}, \mathrm{DMSO}-\mathrm{d}_{6}\right), \delta$, ppm: 156.4 (S-C-NH), 151.1 (C-C-NH), 138.6, 130.2, 129.8, 129.3, 129.24, 129.22, 128.7, 120.1, 115.1, 114.0,

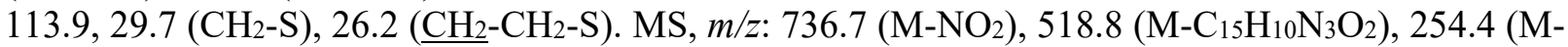
$2 \mathrm{C}_{15} \mathrm{H}_{10} \mathrm{~N}_{3} \mathrm{O}_{2}$ ). Anal. Calcd. For $\mathrm{C}_{38} \mathrm{H}_{30} \mathrm{~N}_{12} \mathrm{O}_{4} \mathrm{~S}_{2}$ (782.2): C, 58.30; H, 3.86; N, 21.47. Found: C, 58.22; $\mathrm{H}, 3.67 ; \mathrm{N}, 21.29$.

1,4-bis((3-(1,3-diphenyl-1 H-pyrazol-4-yl)-1H-1,2,4-triazol-5-yl)thio)butane (7b). Yield 90\%, cream solid; M. p. $300>{ }^{\circ}$ C. FT-IR $(\mathrm{KBr}), v, \mathrm{~cm}^{-1}: 3248(\mathrm{~N}-\mathrm{H}), 3026(\mathrm{C}-\mathrm{H}), 1656,1587,1535,1460$ $(\mathrm{C}=\mathrm{C}$ and $\mathrm{C}=\mathrm{N}), 1384(\mathrm{C}-\mathrm{H}), 1271(\mathrm{C}-\mathrm{S}-\mathrm{C}), 1020,856,778,728 .{ }^{1} \mathrm{H}$ NMR $\left(300 \mathrm{MHz}, \mathrm{DMSO}-\mathrm{d}_{6}\right), \delta$, ppm: 1.87 (br. s, 2H, $\underline{\mathrm{CH}_{2}}-\mathrm{CH}_{2}-\mathrm{S}$ ), 3.07 (br. s, $2 \mathrm{H}, \mathrm{CH}_{2}-\mathrm{S}$ ), 7.47 (t, $\left.J=7.4 \mathrm{~Hz}, 1 \mathrm{H}\right), 7.54-7.62$ (m, $6 \mathrm{H}$ ), $7.82(\mathrm{~s}, 1 \mathrm{H}, \mathrm{CH}-\mathrm{N}), 7.85(\mathrm{~d}, J=8.1 \mathrm{~Hz}, 2 \mathrm{H}), 9.08(\mathrm{~s}, 1 \mathrm{H}, \mathrm{NH}) .{ }^{13} \mathrm{C}$ NMR spectrum $(75 \mathrm{MHz}$, DMSOd6), $\delta$, ppm: 163.7 (S-C-NH), 153.9 (C-C-NH), 152.1, 138.1, 134.8, 131.1, 129.9, 128.9, 127.9, 126.5, 123.6, 118.2, 109.8, $29.9\left(\mathrm{CH}_{2}-\mathrm{S}\right), 27.2\left(\underline{\mathrm{CH}_{2}}-\mathrm{CH}_{2}-\mathrm{S}\right)$. MS, $\mathrm{m} / z$ : 318.5. Anal. Calcd. For $\mathrm{C}_{38} \mathrm{H}_{32} \mathrm{~N}_{10} \mathrm{~S}_{2}$ (692.9): C, 65.87; H, 4.66; N, 20.22. Found, (\%): C, 65.75; H, 4.55; N, 20.08.

1,4-bis((3-(3-(4-chlorophenyl)-1-phenyl-1H-pyrazol-4-yl)-1H-1,2,4-triazol-5-yl)thio)butane (7c). Yield $92 \%$, cream solid; M. p. $300>{ }^{\circ} \mathrm{C}$. IR spectrum (KBr), $v, \mathrm{~cm}^{-1}: 3426,3249(\mathrm{~N}-\mathrm{H}), 2923,2873$ $(\mathrm{C}-\mathrm{H}), 1656,1535,1460(\mathrm{C}=\mathrm{C}$ and $\mathrm{C}=\mathrm{N}), 1384,1271,1020(\mathrm{C}-\mathrm{S}-\mathrm{C}), 1166(\mathrm{C}-\mathrm{Cl}), 856,779,728 .{ }^{1} \mathrm{H}$ NMR spectrum (300 MHz, DMSO-d6), $\delta$, ppm: 1.77 (br. s, $2 \mathrm{H}, \mathrm{CH}_{2}-\mathrm{CH}_{2}-\mathrm{S}$ ), 3.36 (br. s, $2 \mathrm{H}, \mathrm{CH}_{2}-\mathrm{S}$ ), 7.46-7.63 (m, 5H), $7.72(\mathrm{~d}, J=8.1 \mathrm{~Hz}, 2 \mathrm{H}), 7.93(\mathrm{~d}, J=7.8 \mathrm{~Hz}, 2 \mathrm{H}), 8.23(\mathrm{~s}, 1 \mathrm{H}, \mathrm{CH}-\mathrm{N}), 9.18(\mathrm{~s}, 1 \mathrm{H}$, $\mathrm{NH}) .{ }^{13} \mathrm{C}$ NMR spectrum (75 MHz, DMSO-d 6 ), $\delta$, ppm: 153.2 (S-C-NH), 138.1, 134.3, 130.2, 130.1, 129.0, 128.9, 128.7, 128.4, 126.9, 115.2, 115.0, 113.3, $31.8\left(\mathrm{CH}_{2}-\mathrm{S}\right), 28.3\left(\mathrm{CH}_{2}-\mathrm{CH}_{2}-\mathrm{S}\right) . \mathrm{MS}, \mathrm{m} / z: 507.5$ (M- $\left.\mathrm{C}_{15} \mathrm{H}_{10} \mathrm{ClN}_{2}\right), 254.3\left(\mathrm{M}-2 \mathrm{C}_{15} \mathrm{H}_{10} \mathrm{ClN}_{2}\right)$. Anal. Calcd. For $\mathrm{C}_{38} \mathrm{H}_{30} \mathrm{Cl}_{2} \mathrm{~N}_{10} \mathrm{~S}_{2}$ (761.75): C, 59.92; $\mathrm{H}$, 3.97; N, 18.39. Found: C, 59.85; H, 3.82; N, 18.21. 


\section{References}

1. Al-Masoudi I. A., Al-Soud Y. A., Al-Salihi N. J., and Al-Masoudi N. A. (2006) 1,2,4-Triazoles: synthetic approaches and pharmacological importance. Chem. Heterocycl. Compd., 42 (11) 1377-1403.

2. Pearson M. M., Rogers D., Cleary J. D., and Chapman S. W. (2003) Voriconazole: a new triazole antifungal agent. Ann. Pharmacother., 37 (3) 420-432.

3. Greer N. D. (2007) Posaconazole (Noxafil): a new triazole antifungal agent. Proc. (Bayl. Univ. Med. Cent). 20 (2) 188-196.

4. Gural'skiy I. A., Reshetnikov V. A., Omelchenko I. V. Szebesczyk A., Gumienna-Konteckac E., and Fritskya I. O. (2017) Synthesis, crystal structures and spectral characterization of chiral 4-R-1,2,4triazoles. J. Mol. Struct., 1127 164-168.

5. Fan Y. L., Ke X., and Liub M. (2018) Coumarin-triazole hybrids and their biological activities. $J$. Heterocycl. Chem., 55 (4) 791-802.

6. Süleymanoğlu N., Ustabaş R., Direkelc S., Alpasland Y. B., and Ünvere Y. (2017) 1,2,4-Triazole derivative with Schiff base; Thiol-thione tautomerism, DFT study and antileishmanial activity. $J$. Mol. Struct., 1150 82-87

7. Kharb R., Sharma P. C., and Yar M. S. (2011) Pharmacological significance of triazole scaffold. J. Enzyme Inhib. Med. Chem., 26 (1) 1-21.

8. Hu Y. Q., Zhang S., Xu Z., Lv Z. S., Liu M. L., and Feng L. S. (2017) 4-Quinolone hybrids and their antibacterial activities. Eur. J. Med. Chem., 140 335-345

9. Chougala B. M., Samundeeswari S., Holiyachi M., Shastri L. A., Dodamani S., Jalapure S., Dixit S. R., Joshi S. D., and Sunagar V. A. (2017) Synthesis, characterization and molecular docking studies of substituted 4-coumarinylpyrano[2,3-c]pyrazole derivatives as potent antibacterial and antiinflammatory agents. Eur. J. Med. Chem., 125 101-116.

10. Fu N., Wang S., Zhang Y., Zhang C., Yang D., Weng L., Zhao B., and Wang L. (2017) Efficient click chemistry towards fatty acids containing 1,2,3-triazole: design and synthesis as potential antifungal drugs for candida albicans. Eur. J. Med. Chem., 136 596-602.

11. Banu K. M., Dinaker A., and Ananthnarayan C. (1999) Synthesis, characterization of antimicrobial studies and pharmacological screening of some substituted 1,2,3-triazoles. Indian J. Pharm. Sci., 61 (4) 202-205.

12. Chen L. Z., Sun W. W., Bo L., Wang J. Q., Xiu C., Tang W. J., Shi J. B., Zhou H. P., and Liu X. H. (2017) New arylpyrazoline-coumarins: Synthesis and anti-inflammatory activity. Eur. J. Med. Chem., 138 170-181.

13. Coskun D., Erkisa M., Ulukaya E., Coskun M. F., and Ari F. (2017) Novel 1-(7-ethoxy-1benzofuran-2-yl) substituted chalcone derivatives: Synthesis, characterization and anticancer activity. Eur. J. Med. Chem., 136 212-222.

14. Akhtar J., Khan A. A., Ali Z., Haider R., and Yar M. S. (2017) Structure-activity relationship (SAR) study and design strategies of nitrogen-containing heterocyclic moieties for their anticancer activities. Eur. J. Med. Chem., 125 143-189.

15. Gujjar R., Marwaha A., White J., White L., Creason S., Shackleford D. M., Baldwin J., Charman W. N., Buckner F. S., Charman S., Rathod P. K., and Phillips M. A. (2009) Identification of a metabolically stable triazolopyrimidinebased dihydroorotate dehydrogenase inhibitor with antimalarial activity in mice. J. Med. Chem., 52 (7) 1864-1872.

16. Hu Y. Q., Gao C., Zhang S., Xu L., Xu Z., Feng L. S., Wu X., and Zhao F. (2017) Quinoline hybrids and their antiplasmodial and antimalarial activities. Eur. J. Med. Chem., 139 22-47.

17. Duran A., Dogan H. N., and Rollas H. (2002) Synthesis and preliminary anticancer activity of new 1,4-dihydro-3- (3-hydroxy-2- naphthyl)-4-substituted-5H-1,2,4-triazoline-5-thiones. Farmaco., 57 (7) 559-564.

18. Wen X., Zhou Y., Zeng J, and Liu X. (2020) Recent development of 1,2,4-triazole-containing compounds as anticancer agents. Curr. Top. Med. Chem. 20 (16) 1441-1460.

19. Appukkuttan P., Dehaen W., Fokin V. V., and Eycken E. V. (2004) A microwave-assisted click chemistry synthesis of 1,4-disubstituted 1,2,3-triazoles via a copper(I)-catalyzed three-component 
reaction. Org. Lett., 6 (23) 4223-4225.

20. Wamhoff H. (1984) In Comprehensive Heterocyclic Chemistry, Pergamon: Oxford., 5, 669-732.

21. Wu Y. M., Deng J., Fang X., and Chen Q. Y. (2004) Regioselective synthesis of fluoroalkylated [1,2,3]-triazoles by Huisgen cycloaddition. J. Fluor. Chem., 125 (10) 1415-1423.

22. (a) Whiting M., Muldoon J., Lin Y. C., Silverman S. M, Lindstrom W., Olson A. J., Kolb H. C., Finn M. G., Sharpless K. B., Elder J. H., and Fokin V. V. (2006) Inhibitors of HIV-1 protease by using in situ click chemistry. Angew. Chem. Int. Ed., 45 (9) 1435-1439. (b) Lva J. S., Peng X. M., Kishore B., and Zhou C. H. (2014) 1,2,3-Triazole-derived naphthalimides as a novel type of potential antimicrobial agents: synthesis, antimicrobial activity, interaction with calf thymus DNA and human serum albumin. Bioorg. Med. Chem. Lett., 24 (1) 308-313.

23. Chandrika P. M., Yakaiah T., Gayatri G., Kumar K. P., Narsaiah B., Murthy U. S. N., and Rao A. R. R. (2010) Click chemistry: studies on the synthesis of novel fluorous tagged triazol-4-yl substituted quinazoline derivatives and their biological evaluation-theoretical and experimental validation. Eur. J. Med. Chem., 45 (1) 78-84.

24. Wang X., Wan K., and Zhou C. (2010) Synthesis of novel sulfanilamide-derived 1,2,3-triazoles and their evaluation for antibacterial and antifungal activities. Eur. J. Med. Chem., 45 4631-4639.

25. Puig-Basagoiti F, Qing M, Dong H., Zhang B, Zou G, Yuan Z, and Shi P. Y. (2009) Identification and characterization of inhibitors of west nile virus. Antiviral Res., 83 (1) 71-79.

26. Guantai E. M., Ncokazi K., Egan T. J., Gut J., Rosenthal P. J., Smith P. J., and Chibale K. (2010) Design, synthesis and in vitro antimalarial evaluation of triazole-linked chalcone and dienone hybrid compounds. Bioorg. Med. Chem., 18 (23) 8243-8256.

27. Gangu K. K., Maddila S., Maddila S. N., and Jonnalagadda S. B. (2016) Nanostructured samarium doped fluorapatites and their catalytic activity towards synthesis of 1,2,4-triazoles. Molecules, 21 (10) 1281.

28. Patil J. D., and Pore D. M. (2014) [C16 $\mathrm{MPy} \mathrm{AlCl}_{3} \mathrm{Br}$ : An efficient novel ionic liquid for synthesis of novel 1,2,4-triazolidine-3-thiones in water, RSC Adv., 4 (28) 14314-14319.

29. Koparır M., Çetin A., and Cansiz A. (2005) 5-Furan-2yl[1,3,4]oxadiazole-2-thiol, 5-furan-2yl-4H $[1,2,4]$ triazole-3-thiol and their thiol-thione tautomerism. Molecules, 10 (2) 475-480.

30. Jasiński R., and Dresler E., (2020) Review on the question of zwitterionic intermediates in the[3+2] cycloaddition reactions: a critical review. Organics, 1 (1) 49-69.

31. Jahanshahi P., and Mamaghani M. (2019) Chemodivergent, multicomponent-tandem facile synthesis of novel $1 H$-pyrazolo[1,2- $b]$ phthalazine-5,10-dione using acetic acid functionalized imidazolium salt $\{[\mathrm{cmdmim}] \mathrm{I}\}$ as a recyclable catalyst. New J. Chem., 43 (21) 8266-8278.

32. Jahanshahi P., Mamaghani M., Haghbin F., Hossein Nia R., and Rassa M. (2017) One-pot chemoselective synthesis of novel pyrrole-substituted pyrido[2,3- $d]$ pyrimidines using $\left[\gamma-\mathrm{Fe}_{2} \mathrm{O}_{3} @\right.$ HAp-SO $\left.{ }_{3} \mathrm{H}\right]$ as an efficient nanocatalyst. J. Mol. Struct., 1155 520-529.

33. Ahmadiazar M., and Mamaghani M. (2014) Synthesis of (2-iminomethyl)pyridine moiety supported on hydroxyapatite-encapsulated- $\gamma-\mathrm{Fe}_{2} \mathrm{O}_{3}$ as an inorganic-organic hybrid magnetic nanocatalyst for the synthesis of thiazole derivatives under ultrasonic irradiation. Curr. Org. Chem., 22 (13) 1326-1334.

34. Tavakoli F., Mamaghani M., Sheykhan M., Mohammadipour N., and Rassa M. (2018) Ultrasonic activated, highly efficient and regioselective synthesis of a novel pyrrole-linked benzo[f]chromene scaffold in a green media. Curr. Org. Synth., 15 (6) 872-880.

35. Tavakoli F., Mamaghani M., and Sheykhan M. (2019) Introduction of Ag/CuO/MCM-48 as an efficient catalyst for the one-pot synthesis of novel pyran-pyrrole hybrids. Appl. Organomet. Chem., 33 (9) e5083.

36. Saberikhah E., Mamaghani M., Mahmoodi N. O., and Fallah Shojaei A. (2020) Magnetic $\mathrm{Fe}_{3} \mathrm{O}_{4} @ \mathrm{TiO}_{2} @ \mathrm{NH}_{2} @ \mathrm{PMo}_{12} \mathrm{O}_{40}$ nanoparticles: a recyclable and efficient catalyst for convergent one-pot synthesis of pyrido[2,3-d]pyrimidine derivatives. Polycyclic Aromat. Compd., 40 (1) 1-19. 
37. Mamaghani M., and Hossein Nia R. (2021) A review on the recent multicomponent synthesis of pyranopyrazoles. Polycyclic Aromat. Compd., 41 (2) 223-291.

38. Mirfarjood S. A., Mamahgani, M., and Sheykhan, M. (2017) Copper-exchanged magnetic-FAp: surface catalysis in decarboxylative coupling of a-oxocarboxylic acids with formamides. ChemistrySelect., 2 (27) 8650-8657.

39. Mirfarjood S. A., Mamaghani M., and Sheykhan M. (2017) Copper-incorporated fluorapatite encapsulated iron oxide nanocatalyst for synthesis of benzimidazoles. J. Nanostruct. Chem., 7 (4) 359-366.

40. Pourkarim Z., and Nikpassand M. (2020) Synthesis, characterization and application of $\mathrm{Fe}_{3} \mathrm{O}_{4} @ \mathrm{SiO}_{2} @$ Tannic acid nanoparticles: A novel and magnetically recyclable catalyst for one-pot sy nthesis of novel 5-pyrazolin-1,2,4-triazolidine-3-ones (thiones). J. Mol. Struct., 1217128433.

41. Nikpassand M., and Farshami M. J. (2020) One-pot synthesis of novel 3-pyrazolyl-4H-1,2,4triazoles using amino glucose-functionalized silica-coated $\mathrm{NiFe}_{2} \mathrm{O}_{4}$ nanoparticles as a magnetically separable catalyst. J. Clust. Sci., 1-8. https://doi.org/10.1007/s10876-020-01855-y

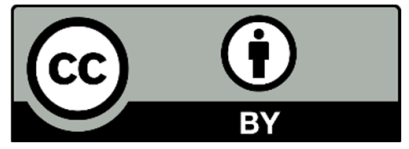

(C) 2021 by the authors; licensee Growing Science, Canada. This is an open access article distributed under the terms and conditions of the Creative Commons Attribution (CC-BY) license (http://creativecommons.org/licenses/by/4.0/). 